\author{
В. В. Васильківська

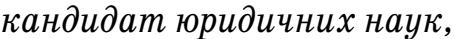 \\ асистент кафедри адліністративного і фінансового права \\ Національного університету «Одеська юридична академія»
}

\title{
ВИМОГИ, ЩО ВИСУВАЮТЬСЯ ДО ДЕРЖАВНОГО СЛУЖБОВЦЯ: ЗАКОРДОННИЙ ДОСВІД ТА ПЕРСПЕКТИВИ РОЗВИТКУ В УКРАЇНІ
}

Питання публічного управління та державної служби як об'єкта наукового пошуку були і залишаються одним із основних напрямів теорії адміністративного права. Питання правового статусу державного службовця, особливостей його правового регулювання не тільки залишаються актуальними, важливими і своєчасними, але й набувають особливого значення у контексті реформування системи публічного управління, удосконалення чинного законодавства про державну службу та адаптації інституту державної служби до стандартів Європейського Союзу. Розвиток комп'ютерних технологій, електронних сервісів та підходів до управлінських процесів загалом породжують новий рівень вимог та умінь осіб, які мають, власне, реалізувати зазначені управлінські процеси. 3 огляду на сказане суттєво зростають роль і значення інституту державної служби, а також набувають особливої ваги питання правового статусу державних службовців як безпосередніх виконавців, які забезпечують реалізацію завдань і функцій держави. Побудова професійної, авторитетної, дієвої та ефективної державної служби є неможливою без висококваліфікованих державних службовців 3 відповідним рівнем професійної компетенції. Удосконалення чинного законодавства про державну службу, безперечно, вирішило низку його проблем (політичної неупередженості, дисциплінарної відповідальності, оплати праці, припинення державної служби тощо), але водночас поставило нові питання, які потребують негайного нормативного вирішення та теоретичного забезпечення. У контексті зазначеного великого значення набуває не тільки питання правового статусу державного службовця, але й питання щодо правового регулювання цього статусу, створення належних засад, умов та гарантій його реалізації.

Питанням правового статусу державного службовця приділялася певна увага в юридичній науці і насамперед у теорії адміністративного права. Зокрема, на рівні дисертаційних (Д.В. Балух, Л.Р. Біла-Тіунова, Ю.Р. Битяк, М.І. Іншин, Л.М. Корнута, О.М. Стець та ін.) та монографічних досліджень (В.Б. Авер'янов, І.П. Голосніченко, С.Д. Дубенко, С.В. Ківалов, Т.О. Коломоєць та ін.). Необхідно зазначити, що наукові напрацювання та теоретичні положення теоретиків стали науково-теоретичним підгрунтям ста- новлення і розвитку як теорії державної служби, так і правового інституту державної служби. Водночас подальший розвиток публічної служби та адаптація інституту державної служби до стандартів Європейського Союзу, а також відсутність комплексних досліджень правового статусу державних службовців та з'ясування вимог, що можуть висуватися до державного службовця як представника влади, зумовлюють актуальність обраної теми дослідження.

Тому метою статті є з'ясування та аналіз на основі зарубіжної практики вимог, що висуваються до державного службовця, та формулювання пропозиції щодо удосконалення вітчизняного законодавства.

Слід зазначити, що у широкому (доктринальному) розумінні поняття «правообмеження» охоплює такий чинник, як «вимоги». Окремі науковці розглядають поняття «правообмеження» саме у широкому розумінні. Натомість у вузькому (нормативному) розумінні цей чинник не належить до змісту правообмежень і саме тому, дотримуючись цієї точки зору, слід розглянути поняття, зміст та види поняття «вимоги» саме у контексті елемента статусу державного службовця.

Звернення до тлумачення поняття «вимога» свідчить про різні визначення цього поняття, зокрема як: а) сувора вказівка, рівносильна наказу (форма вираження вимоги може бути різною (усна, письмова, по телефону тощо), зміст вимоги може бути виражено як у різкій, грубій формі, так і вишукано ввічливо) [7]; б) норми, правила, яким хтоабо що-небудь мають підлягати [10]. На підставі вищенаведеного слід зазначити, що у всіх названих визначеннях вимога характеризується владним одностороннім характером, який не допускає вибору варіанту поведінки особи, якій її адресовано.

У разі характеристики вимоги як елемента правового статусу державного службовця важливо акцентувати увагу на тому, що йдеться тільки про правову вимогу, тобто вимогу, визначену нормою права. I хоча у нормативному обігові йдеться про «вимоги», мається на увазі, що це саме «правові вимоги». Аналіз чинного законодавства про державну службу свідчить про те, що законодавець чітко не розмежував поняття "вимоги» й «обмеження». Більше того, в окремих випадках обмеження щодо державних службовців визначаються 
через поняття «вимога», зокрема ст. 27 Закону «Про запобігання корупції» визначає, що «у разі виникнення обставин, що порушують вимоги частини першої цієї статті («державні службовці не можуть мати у прямому підпорядкуванні близьких осіб...» - це не є вимогою, а є обмеженням) $<. .>$ відповідні особи вживають заходів щодо усунення таких обставин» [3].

Дослідження вимог у державній службі слід розпочати з основоположних вимог, тобто тих, які визначено у ч. 2 ст. 38 Конституції України: «громадяни користуються рівним правом доступу до державної служби...». Таким чином, у цьому разі йдеться про громадянство України як єдиної конституційної вимоги до державних службовців. Слід зазначити, що цьому питанню уже було присвячено низку публікацій [6; 8], однак слід звернути увагу на два важливі моменти: подвійне громадянство і зарубіжний досвід вирішення цього питання. Натепер в Україні є проблема 3 подвійним громадянством, яке певною мірою торкнулося і державних службовців. Відповідно до чинного законодавства [4] в Україні $\epsilon$ єдине громадянство і державним службовцем може бути тільки громадянин України. Набуття громадянства іншої держави є підставою для припинення державної служби (п. 1 ч. 1 ст. 84 Закону «Про державну службу» [1]). Проблема полягає у тому, що чинним законодавством України не передбачено відповідальності за подвійне громадянство, хоча такі випадки мають місце, зокрема, у Закарпатській області, і це питання потребує негайного вирішення.

Наступним важливим моментом є зарубіжний досвід вирішення питання громадянства у публічній службі і визначення можливостей використання зарубіжного досвіду в умовах України. Так, дещо інакше вирішуються питання щодо громадянства осіб, які вступають на публічну службу, у країнах Європейського Союзу. Зокрема, відповідно до $§ 7$ Федерального закону ФРН «Про статус чиновників» [9, с. 227] «призначеним чиновником може бути тільки той, хто $є$ німцем на підставі ст. 116 Основного закону або має громадянство однієї з держав-членів Європейської співдружності». Водночас для зайняття певних посад у ФРН вимога громадянства $€$ абсолютною: «якщо цього вимагають відповідні завдання, то чиновником може бути призначений тільки німець», тобто йдеться насамперед про діяльність, пов' язану з державною таємницею, або про вищі посади чиновників. Окрім цього, звертає на себе увагу положення, відповідно до якого федеральний міністр внутрішніх справ (який здійснює управління публічною службою у ФРН) може робити індивідуальні винятки та за наявності нагальної службової потреби в роботі чиновників приймати іноземних громадян навіть 3-поза меж Європейського Союзу. Однак вимога громадянства у більшості зарубіжних держав є досить жорсткою. Як видається, натепер в Україні питання громадянства для державних службовців має бути досить чітко i жорстко врегульоване чинним законодавством, у т.ч. і щодо подвійного громадянства.

Аналіз чинного законодавства про державну службу свідчить про те, що вимога за формою свого вираження може бути чітко визначена статтею закону (ст. 20 , п. 2 ч. 3 ст. 22 , п. 5 ч. 4 ст. 23 Закону «Про державну службу» [1], ст. 49 Закону «Про Національну поліцію України» [5], ст. 27 Закону «Про прокуратуру» тощо) або може бути передбачена в інших статтях без чіткого акценту на тому, що це положення є вимогою, зокрема ст. 10 «Політична неупередженість», ст. 19 «Право на державну службу» Закону «Про державну службу» тощо.

Згідно зі ст. 19 Закону «Про державну службу», право на державну службу мають повнолітні громадяни України, тобто особи, які досягли 18-річного віку. Щодо досягнення повноліття слід зазначити, що ця вимога є новітньою порівняно із Законом «Про державну службу» 1993 року і такою, що відповідає сутності державної служби. Тільки особа, яка досягла 18-річного віку, тобто володіє повною дієздатністю, може претендувати на посаду державної служби. Такий підхід є цілком правовим, оскільки володіти державно-владними повноваженнями може тільки особа, яку наділено насамперед державно-публічною дієздатністю (конституційною, адміністративною) і вправі цими повноваженнями розпоряджатися відповідно до чинного законодавства. Щодо зарубіжного досвіду, то законодавство зарубіжних країн закріплює як мінімальний вік вступу на публічну службу, так і максимальний. Загальний мінімальний вік у більшості європейських країн становить 18 років, у деяких країнах - 20 років (Данія), а для зайняття багатьох посад цей вік $є$ більш високим, що зумовлено насамперед потребою одержання відповідної освіти й підготовки. Зокрема, значно вищим є мінімальний вік для зайняття постійних посад у ФРН, який становить 27 років, оскільки для того, щоб претендувати на ці посади, необхідно пройти підготовчу службу [9, с. 227]. Окрім мінімального віку, зарубіжним законодавством передбачається і максимальний вік вступу на державну службу, що зумовлено тим, що: по-перше, у країнах системи кар'єри органи публічної адміністрації не зацікавлені у прийомі на службу на невеликі строки осіб, які досягли певного віку, враховуючи, що відставка службовців за загальним правилом наступає у 60-65 років, тобто держава намагається якомога ефективніше інвестувати кошти на розвиток кадрового потенціалу; по-друге, вважається, що 
після досягнення певного віку особа не може покладені завдання і функції виконувати настільки ефективно, як цього вимагає характер служби. Єдиного систематизованого підходу у вирішенні цього питання немає, і в кожній країні встановлюються свої вимоги щодо цього віку: Австрія - 40, Франція - 45, Бельгія - 50 років. Водночас у багатьох країнах (Нідерланди, Швеція, Велика Британія), як і в Україні, подібних вікових обмежень немає, однак є вимога щодо того, що публічний службовець має бути здатний служити протягом реального періоду до відставки.

Ще однією вимогою, яку необхідно дослідити, є вимога щодо вільного володіння державною мовою. Слід зазначити, що ця вимога $є$ новітньою порівняно із Законом «Про державну службу» 1993 року, який такої вимоги не передбачав. Відповідно до ст. 10 Конституції України державною мовою в Україні є українська. Під поняттям «державна мова» слід розуміти, що українська мова є обов'язковим засобом спілкування на всій території України під час здійснення повноважень органами державної влади та органами місцевого самоврядування (мова нормативних актів, діловодства, документації тощо), а також в інших публічних сферах суспільного життя. Зокрема, відповідно до чинного законодавства застосування української мови визначено щодо: а) розгляду звернень громадян; б) діяльності Збройних сил України; в) видання друкованої продукції, призначеної для службового та ужиткового користування, що розповсюджується через державні підприємства, установи та організації (бланки, форми квитанції, квитки, посвідчення тощо); г) висвітлення діяльності органів державної влади та органів місцевого самоврядування в Україні засобами масової інформації; г) оформлення митних документів тощо. Окрім зазначеного, володіння державною мовою є обов'язковою умовою для прийняття до громадянства України (п. 5 ст. 9 Закону «Про громадянство»). Службові особи державних органів, установ і організацій мають володіти українською мовою. Аналіз зарубіжного законодавства свідчить, що володіння державною мовою - це вимога, яка зумовлена характером діяльності публічних службовців, що полягає в активному використанні i, відповідно, знанні державної мови для виконання покладених завдань i функцій. Вимога володіння державною мовою зазвичай прямо встановлюється в державах, де є чималі іншомовні національні групи, наприклад, в Естонії, Литві, Латвії. У мононаціональних країнах (Польща, Болгарія) у законах про публічну службу цієї умови не передбачено [9, с. 101].

Вимоги висуваються до державних службовців усіх видів державної служби, однак вони є різними за своїм змістом. Так, відповідно до 49 Закону «Про Національну поліцію України» [5] на службу в поліції може бути прийнято громадян України віком від 18 років, які мають повну загальну середню освіту, незалежно від раси, кольору шкіри, політичних, релігійних та інших переконань, статі, етнічного та соціального походження, майнового стану, місця проживання, які володіють українською мовою. При цьому вимоги щодо рівня фізичної підготовки для поліцейських та кандидатів, які вступають на службу в поліцію, затверджує Міністерство внутрішніх справ України.

Можна також навести приклад ст. 13 Закону «Про дипломатичну службу», що передбачає загальні (передбачені Законом «Про державну службу») та спеціальні вимоги до осіб, які претендують на вступ на дипломатичну службу: а) наявність вищої освіти із ступенем не нижче магістра - для дипломатичних службовців; б) володіння відповідним рівнем професійної компетентності згідно з вимогами, визначеними Міністерством закордонних справ України; в) володіння іноземними мовами в обсязі, необхідному для виконання посадових обов'язків; г) стан здоров'я, який дає змогу бути направленим у довготермінове відрядження, підтверджений документом, виданим у встановленому законодавством порядку; г) відсутність обставин, що можуть перешкоджати виконанню посадових обов'язків під час роботи в системі органів дипломатичної служби [2].

Як уже зазначалося вище, низка вимог, що висуваються до державних службовців, передбачена іншими статтями Закону «Про державну службу», в яких чітко не визначено, що це саме "вимоги». Так, п. 9 ч. 1 ст. 8 «Основні обов'язки державного службовця» передбачає, що державний службовець зобов' язаний «додержуватися вимог законодавства у сфері запобігання і протидії корупції». При цьому варто звернути увагу на те, що в Законі «Про запобігання корупції» [3] більшість статей (ст.ст. 22 27) передбачає обмеження, а не вимоги.

Таким чином, вимога - це односторонній владний припис кількісного або якісного характеру, якому мусить відповідати державний службовець. Вимоги слід класифікувати на види за: 1) за колом державних службовців: а) загальні (громадянство України, володіння українською мовою, досягнення 18-річного віку); б) спеціальні (політична неупередженість/безпартійність/ політична нейтральність; загальний стаж роботи; досвід роботи на посадах/у сфері; вільне володіння іноземною мовою; повна загальна середня освіта; ступінь вищої освіти; рівень фізичної підготовки; особисті якості; стан здоров'я; відсутність обставин, що можуть перешкоджати виконанню посадових обов'язків тощо); 2) змістом: а) кількісні (2 роки стажу роботи, досягнення 18-річного віку); б) якісні (стан здоров'я, особисті якості, вільне володіння іноземною мовою тощо). 


\section{Jimepamypa}

1. Про державну службу : Закон України від 10.12.2015 p. Дата оновлення: 21.12.2016 p. URL: http://zakon2.rada.gov.ua/laws/show/889-19 (дата звернення: 12.05.2019).

2. Про дипломатичну службу : Закон України від 05.04.2018 р. Дата оновлення: 05.04.2018 р. URL: http://zakon.rada.gov.ua/laws/show/2449-19 (дата звернення: 25.05.2019 р.).

3. Про запобігання корупції : Закон України від 14.10.2014 р. Дата оновлення: 09.02.2017 p. URL: http://zakon2.rada.gov.ua/laws/show/1700-18 (дата звернення: 12.05.2019 р.).

4. Про громадянство : Закон України від 18.01.2001 p. Дата оновлення: 19.02.2016 p. URL: http://zakon.rada.gov.ua/laws/show/2235-14 (дата звернення: 25.05 .2019 р.).

5. Про Національну поліцію України : Закон України від 02.97.2015 р. Дата оновлення: 19.06.2018 р. URL: http://zakon.rada.gov.ua/laws/show/580-19 (дата звернення: 25.06.2019 р.).

6. Битяк Ю.П. Державна служба в Україні: організаційно-правові засади : монографія. Харків : Право, 2005. 304 c.

7. Вимога : URL: http://bibliograph.com.ua/ugolovnoe-pravo-3/139.htm (дата звернення: 25.05.2019 р.)

8. Ківалов С.В., Біла-Тіунова Л.Р. Публічна служба в Україні : підручник для студентів вищих навчальних закладів. Одеса : Фенікс, 2009. 688 с.

9. Публічна служба. Зарубіжний досвід та пропозиції для України / за заг. ред. В.П. Тимощука, А.М. Школика. Київ : Конус-Ю, 2007. 735 с. С. 427-454.

10. Словник української мови. Академічний тлумачник словник : в 11 т. T. 1.1970. C. 434. URL: http:// sum.in.ua/s/vymogha (дата звернення: 25.05.2019 p.).

11. Тлумачний словник сучасної української мови / за ред. докт. філол. наук, проф. В.С. Калашника. Харків : Белкар-книга, 2005. 800 с.

\section{Анотація}

Васильківська В. В. Вимоги, що висуваються до державного службовця: закордонний досвід та перспективи розвитку в Україні. - Стаття.

У статті досліджується питання теоретичного та законодавчого визначення вимог, що висуваються до державного службовця. Звертається увага на основні особливості вимог до державних службовців окремих видів державних служб. Проводиться аналіз чинного зарубіжного законодавства в частині визначення вимог, що висуваються до державних службовців, та аргументується необхідність, а також перспективи удосконалення подальшого нормативного розвитку України.

Зазначається, що суттєво зростають роль і значення інституту державної служби, а також набувають особливої ваги питання правового статусу державних службовців як безпосередніх виконавців, які забезпечують реалізацію завдань і функцій держави. Побудова професійної, авторитетної, дієвої та ефективної державної служби є неможливою без висококваліфікованих державних службовців з відповідним рівнем професійної компетенції. Удосконалення чинного законодавства про державну службу, безперечно, вирішило низку його проблем, але водночас поставило нові питання, які потребують негайного нормативного вирішення та теоретичного забезпечення. У контексті зазначеного великого значення набуває не тільки питання правового статусу державного службовця, але й питання щодо правового регулювання цього статусу, створення належних засад, умов та гарантій його реалізації. Звернення до тлума- чення поняття «вимога» свідчить про різні визначення цього поняття, зокрема як сувора вказівка, рівносильна наказу, зміст вимоги може бути виражено як у різкій, грубій формі, так і вишукано ввічливо. На підставі вищенаведеного слід зазначити, що у всіх названих визначеннях вимога характеризується владним одностороннім характером, який не допускає вибору варіанту поведінки особи, якій її адресовано.

Під час характеристики вимоги як елемента правового статусу державного службовця важливо акцентувати увагу на тому, що йдеться тільки про правову вимогу, тобто вимогу, визначену нормою права. I хоча у нормативному обігові йдеться про "вимоги», мається на увазі, що це саме «правові вимоги». Аналіз чинного законодавства про державну службу свідчить про те, що законодавець чітко не розмежував поняття «вимоги» й «обмеження».

Поряд із тим встановлено, що вимога - це односторонній владний припис кількісного або якісного характеру, якому має відповідати державний службовець. Вимоги слід класифікувати на види за: 1) за колом державних службовців: а) загальні (громадянство України, досягнення 18-річного віку); б) спеціальні (політична неупередженість; загальний стаж роботи; досвід роботи на посадах; вільне володіння іноземною мовою; повна загальна середня освіта; ступінь вищої освіти; рівень фізичної підготовки; особисті якості; стан здоров’я; відсутність обставин, що можуть перешкоджати виконанню посадових обов'язків тощо); 2) змістом: а) кількісні (2 роки стажу роботи, досягнення 18-річного віку); б) якісні (стан здоров'я, особисті якості, вільне володіння іноземною мовою тощо).

Ключові слова: публічне управління, державна служба, законодавчі вимоги, правообмеження.

\section{Summary}

Vasylkivska $V$. V. Requirements for a civil servant: foreign experience and prospects of development in Ukraine. - Article.

The article deals with the issue of theoretical and legal definition of the requirements put forward for a civil servant. Attention is drawn to the main features of the requirements of civil servants of certain types of public services. An analysis of current foreign law is being carried out in relation to the definition of requirements for civil servants and the necessity to argue, as well as prospects for improving further normative development of Ukraine.

It is noted that the role and importance of the civil service institution is growing significantly, as well as the issue of the legal status of civil servants, as direct executors, which ensure the fulfillment of the tasks and functions of the state, are of particular importance. Building a professional, authoritative, efficient and effective civil service is impossible without highly qualified civil servants with an appropriate level of professional competence. The improvement of the current law on civil service has undoubtedly solved a number of its problems, but at the same time raised new questions that require immediate regulatory resolution and theoretical support. In the context of the mentioned important matters, not only the question of legal status of a civil servant, but also the question of legal regulation of this status, the creation of proper principles, conditions and guarantees of its implementation. An appeal to the interpretation of the concept of "requirement» indicates the various definitions of this concept, in particular, as a strict indication, is equivalent to the order, the content of the claim can be expressed in a sharp, rough form, and refined politely. Based on the foregoing, it should be noted that in 
all of these definitions the requirement is characterized by a one-sided power that does not allow the choice of the behavior of the person to whom it is addressed.

When characterizing the requirement as an element of the legal status of a civil servant, it is important to emphasize the fact that it is only a legal requirement, that is, the requirement defined by the rule of law. And although the normative treatment refers to "requirements», it means that these are «legal requirements». Analysis of the current legislation on civil service shows that the legislator did not clearly distinguish the notion of "requirements» and «restrictions».

At the same time, it has been established that the requirement is a one-sided imperative prescription of a quan- titative or qualitative nature, to which a civil servant must answer. Requirements should be classified into types for: 1) by the general public: a) general (citizenship of Ukraine, reaching 18 years of age); b) special (political impartiality; general work experience; experience in the positions; fluency in a foreign language; complete general secondary education; higher education; level of physical training; personal qualities; state of health; absence of circumstances that may interfere with the performance of official duties, etc.); 2) content: a) quantitative (2 years of work experience, reaching 18 years of age); b) qualitative (state of health, personal qualities, fluency in a foreign language, etc.).

Key words: public administration, public service, legislative requirements, legal restrictions. 